- The Levy o Economics Institute of Bard College
Strategic Analysis

April 2009/2

\title{
Recent Rise in Federal Government and Federal Reserve Liabilities: Antidote to a Speculative Hangover
}

DIMITRI B. PAPADIMITRIOU and GREG HANNSGEN

As shown in recent Federal Reserve (Fed) flow-of-funds data, federal government liabilities rose sharply in 2008 (Figure 1). Who holds these new liabilities, and what effects will they have on the economy? Some economists and politicians warn of impending inflation. Below we focus on one positive effect-a badly needed improvement of private sector balance sheets-and suggest some of the reasons why it is unlikely that the surge in Fed and federal government liabilities will cause excessive inflation.

Figure 1 is divided into the liabilities of the federal government (which technically does not include Federal Reserve banks) and the
Fed. It does not include liabilities that these two entities owe to each other, or the securities held by the Social Security trust funds. The liabilities of the Fed mostly comprise currency in circulation and bank reserves held at the Fed. The liabilities of the federal government are of course mostly securities issued by the Treasury Department. The government's liabilities have been growing at an accelerated rate mainly because of rising deficit spending. As the Fed begins its recently announced purchases of longer-term Treasury bonds this spring, rising deficits will probably be partly reflected in further increases in Fed liabilities, rather than only in Treasury securities.

The federal government rapidly expanded its liabilities in $2008 \ldots$

Figure 1 Liabilities on the Consolidated Federal Government / Federal Reserve Balance Sheet

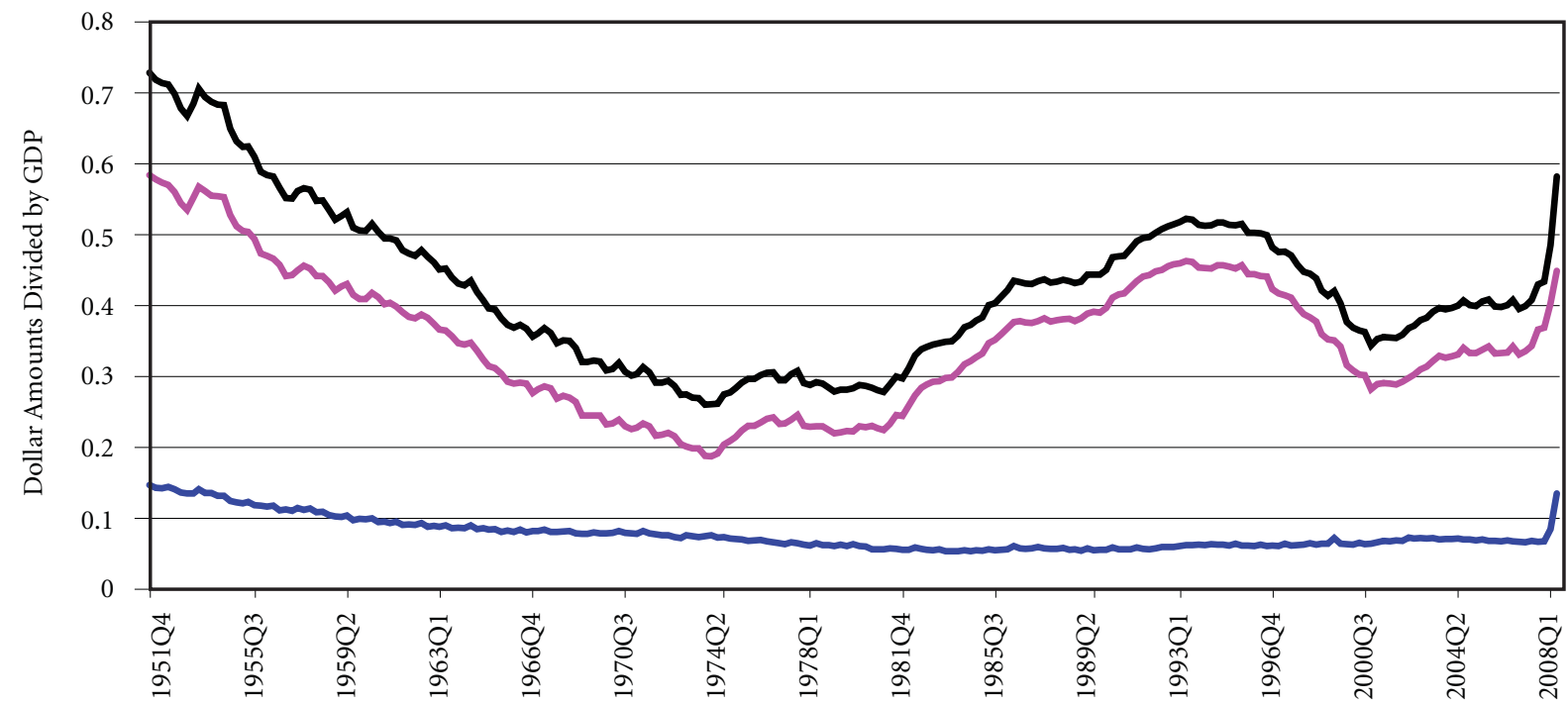

Total

Federal Government Liabilities, Excluding Liabilities to Federal Reserve/GDP

Federal Reserve Liabilities, Excluding Liabilities to Federal Government/GDP

Note: Series shown in blue equals total Fed liabilities minus checkable deposits due to federal government; series shown in fuschia includes total federal government liabilities minus Treasury securities held by the Fed minus nonmarketable securities held by pension funds minus Treasury currency held by the Fed. Data not seasonally adjusted. 
Concern has grown that the increase in federal government and Fed liabilities, and especially money, will cause a large increase in inflation. But demand for goods and services is very weak, making a sudden rise in prices unlikely at this time. Rather than seeing the jump in money and government bonds as fuel for a surge in spending, it can better be seen as a life raft for sectors that have found the value of their overall portfolios shrinking dramatically. The personal sector's financial net worth fell by nearly $\$ 8$ trillion over the last year, according to the Fed data (see Figure 2, which shows financial assets and liabilities divided by GDP). Fed and federal government liabilities are necessarily assets of either the U.S. private sector or other countries. Now that the bubble in risky assets has burst, households have become risk averse rather than yield hungry, and building up a reserve of safe assets will be a salutary antidote to speculative fever. A similar series of events occurred during World War II and the ensuing years, when banks and households eagerly bought federal debt securities, after witnessing a massive loss of wealth in the 1929 stock market crash and the Great Depression. Hyman P. Minsky (1986, pp. 33-37) wrote that a period of serious financial turmoil in 1975 did not become a depression partly because of these balance-sheet effects of government deficits.

Fed data also show how deficits are affecting the balance sheets of various sectors of the economy. Figure 3 demonstrates that investors in the rest of the world, which include the Chinese central bank, have been big net buyers of such securities over the past two years. In March, Chinese Premier Wen Jiabao expressed "worry" about the safety of these assets (Wines 2009). But while it is possible that the value of all dollar-denominated assets will fall in coming years, default on debts that are backed by the full faith and credit of the United States is virtually impossible. This is why many U. S. sectors have been buying Treasuries too. In the last two quarters of 2008, as investors digested bad financial news, domestic money market mutual funds also bought over $\$ 310$ billion in Treasury debt, and domestic life insurance companies and funding corporations (a financial category that includes entities set up by the federal government to clean up risky assets at Bear Stearns and AIG) made large net acquisitions as well. Who, in turn, has been buying money market mutual fund shares? Figure 4 shows that households, nonfinancial businesses, and funding corporations have been buying these funds. These sectors increased their money fund balances by $\$ 167$ billion, $\$ 50$ billion, and $\$ 172$ billion, respectively. So, many of the new government bonds are flowing to sectors where they are badly needed for their ability to stabilize net worth, either directly or through money market mutual funds.

The main sources of growth in the Fed's liabilities were currency in circulation, which has risen steadily over the past year, and bank reserves, which jumped by over $\$ 650$ billion starting last fall

... but personal sector balance sheets need an infusion.

\section{Figure 2 Personal Sector Financial Assets and Liabilities}

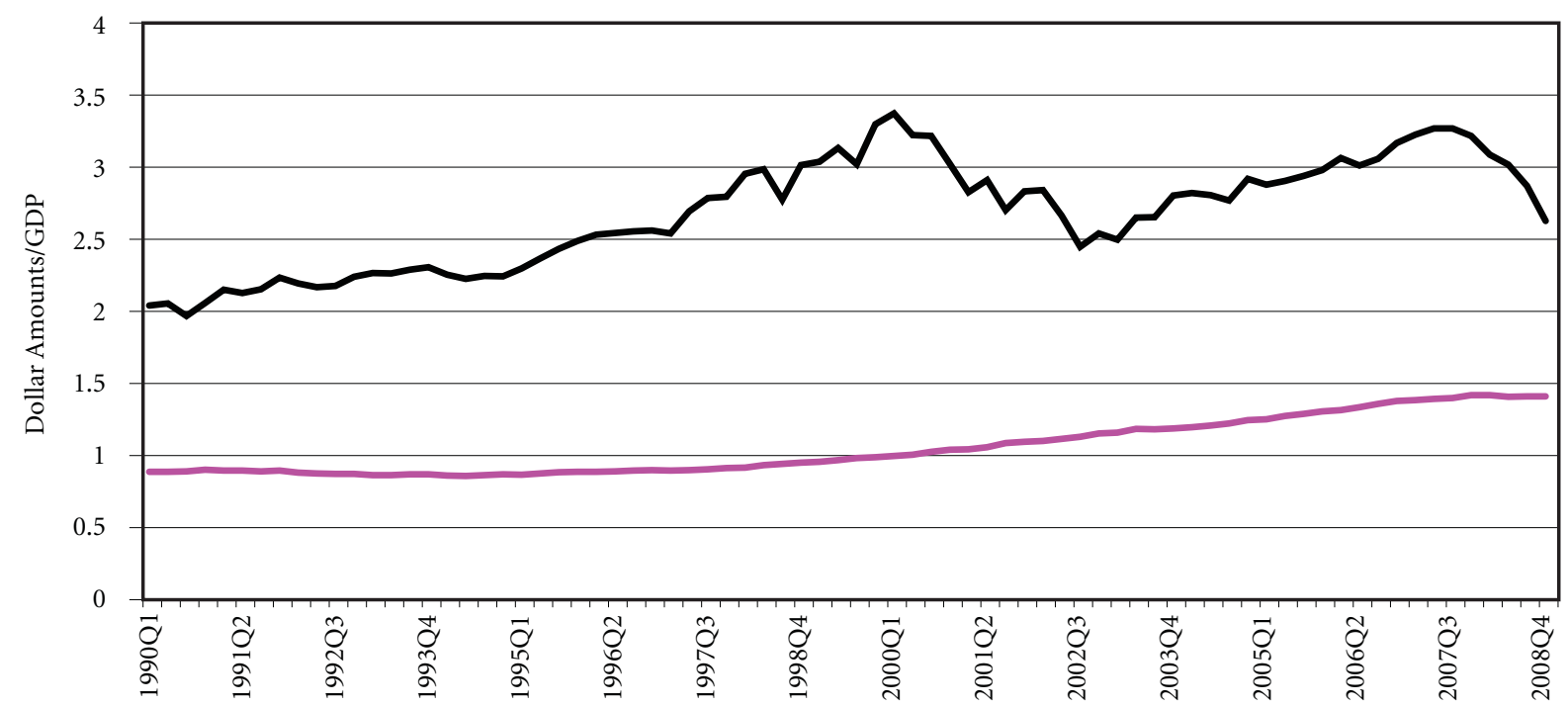

Financial Assets/GDP

Financial Liabilities/GDP

Notes: Personal sector comprises households, nonprofit organizations, and nonfarm, noncorporate business. Data not seasonally adjusted.

Sources: Assets and liabilities, Federal Reserve; GDP, Bureau of Economic Analysis 
as the Fed battled the financial crisis. Bank reserves accounted for the bulk of the rise in "high-powered" money. Of course, many economists have argued that the supply of money is a key driver of inflation. But any plausible scenario in which the excess reserves somehow caused a surge in inflation would involve vastly increased bank lending, which is unlikely to occur in a recessionary environment: both the banks and potential borrowers will be wary of new debt as long as the economy is so weak. On the other hand, once the financial system is running smoothly, a lack of reserves would not act as a restraint on possibly excessive credit: banks will have no trouble obtaining reserves at the going rate on the federal funds market or by selling liabilities such as large certificates of deposit. In a recent speech, Fed Chairman Ben Bernanke (2009, p. 6) explained several tools that the Fed has at its disposal to mop up reserves when it needs to do so.

Concerns about inflation distract attention from the most important effects of increased deficits_-including impacts on balance sheets-that will eventually help stabilize the economy. Note that Figure 1 shows a high, but certainly not unprecedented, level of federal liabilities. (The 1940s and 1950s precedent was accompanied by inflation, especially immediately after the war, but it subsided by 1952 and did not devastate the nation as the Depression had.) It will take some time for the private sector to rebuild its balance sheets, and putting the brakes on either government spending or intervention in the financial sector would only inhibit that effort.

While foreign investors have been buying most of the new Treasury debt securities, money market mutual funds were also big net purchasers in $2008 \ldots$

Figure 3 Treasury Securities Holdings by Sector

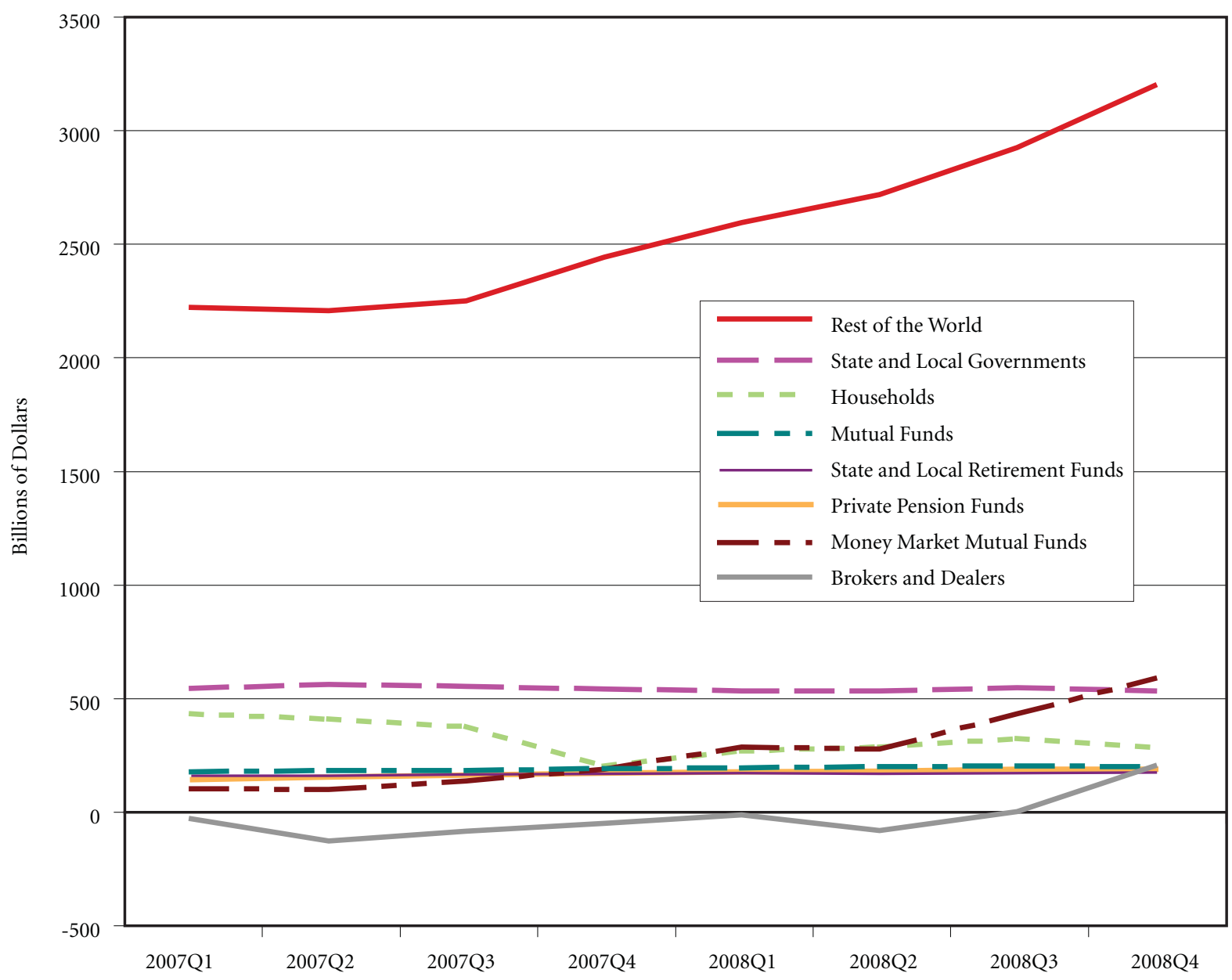

Note: Chart shows all sectors that held more than $\$ 100$ billion in Treasury securities as of the fourth quarter in 2008. Data not seasonally adjusted.

Source: Federal Reserve 
... and risk-averse domestic households and businesses rushed to invest in these funds.

Figure 4 Money Market Mutual Fund Holdings by Sector

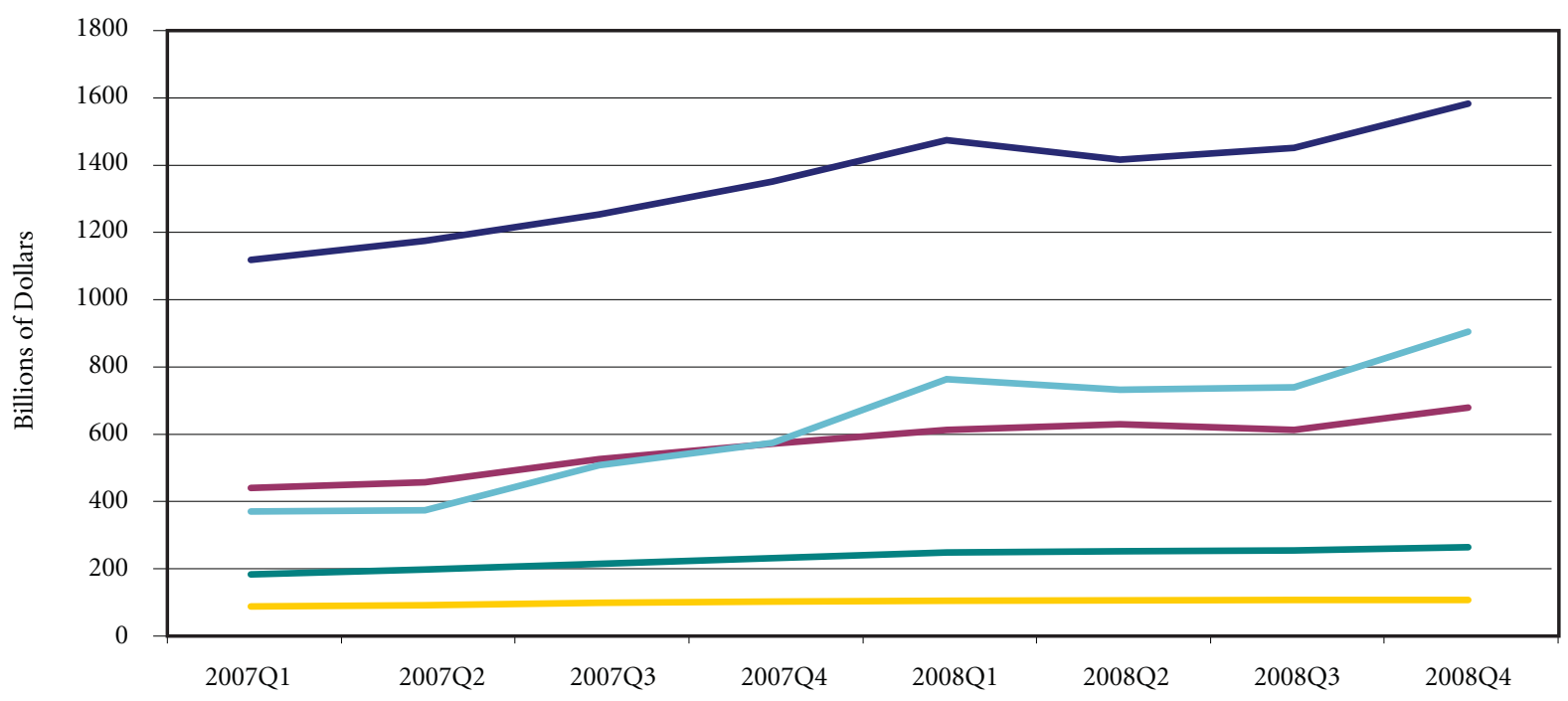

Households

Nonfinancial, Corporate Business

Funding Corporations

Life Insurance Companies

Nonfarm, Noncorporate Business

Note: Chart shows all sectors that held more than $\$ 100$ billion in money market mutual funds as of the fourth quarter, 2008. Data not seasonally adjusted.

Source: Federal Reserve

\section{References}

Bernanke, B. 2009. "The Federal Reserve's Balance Sheet." Speech at the Federal Reserve Bank of Richmond 2009 Credit

Markets Symposium, Charlotte, N.C., April 3.

Minsky, H. P. 1986. Stabilizing an Unstable Economy. New Haven,

Conn.: Yale University Press.

Wines, M. 2009. "China 'Worried' about Safety of U.S.

Treasuries.” The New York Times, March 14.

The Levy Institute's Macro-Modeling Team consists of Distinguished Scholar WYNNE GODLEY, President DIMITRI B. PAPADIMITRIOU, and Research Scholars GREG HANNSGEN and GENNARO ZEZZA. All questions and correspondence should be directed to Professor Papadimitriou at 845-758-7700 or dbp@levy.org. 